\title{
Economic Improvement of Nagari Gunuang Rajo Community, Batipuh, Tanah Datar
}

\author{
Peningkatan Ekonomi Masyarakat Nagari Gunuang Rajo Kecamatan Batipuh Kabupaten \\ Tanah Datar \\ Kurnia Illahi Manvi *)1, Lise Asnur 2, Arif Ardian 3, Retnaningtyas Susanti 4 \\ 1234 Fakultas Pariwisata dan Perhotelan, Universitas Negeri Pandang... 1234 \\ *)Corresponding author, $\leqq$ sretnaningtyas@yahoo.com
}

Diterima 03/12/2019;

Revisi 04/01/2020;

Publish 01/02/2020

\section{Kata kunci:}

peningkatan ekonomi, potensi, masyarakat, pariwisata, Nagari

Gunung Rajo

\begin{abstract}
Abstrak
Nagari Gunung Rajo merupakan salah satu daerah di Kecamatan Batipuh, Kabupaten Tanah Datar, Provinsi Sumatera Barat yang terkenal dengan potensinya berupa buah Durian. Potensi tersebut belum menjadi prioritas untuk dikembangkan sebagai peluang ekonomi yang lebih besar. Upaya untuk memperoleh peningkatan ekonomi masyarakat mulai menjadi salah satu program Nagari, dan dimulai dengan melakukan kerjasama dengan Universitas Negeri padang melalui Lembaga Penelitian dan Pengabdian Masyarakat (LP2M). Kerjasama dilakukan dengan tujuan meningkatkan peluang ekonomi masyarakat melalui program kegiatan dari tim pengabdi di lingkungan UNP. Hal tersebut melatarbelakangi penelitian tentang potensi di Nagari Gunung Rajo dan upaya untuk meningkatkan perekonomian masyarakatnya. Metode yang digunakan dalam penelitian ini adalah pendekatan kualitatif dengan teknik analisa deskriptif kualitatif. Observasi lapangan dan wawancara kepada para pihak yang memiliki informasi kunci terkait Nagari dilakukan untuk memperoleh data, kemudian diolah dengan memilah seluruh informasi, dan disajikan sehingga menjad informasi yang mudah dipahami oleh pembaca. Hasil penelitian menunjukkan bahwa masyarakat masih mengalami permasalahan dalam memanfaatkan potensi yang dimiliki. Upaya yang tepat untuk dilakukan adalah pariwisata minat khusus dengan tema kuliner berbahan dasar durian. Kehadiran tim pengabdi dari Fakultas Pariwisata dan perhotelan UNP menjadi salah satu strategi efektif dalam membantu masyarakat mengembangkan potensinya.
\end{abstract}




\section{Suluah Bendang: Jurnal Ilmiah Pengabdian Kepada Masyarakat}

\section{PENDAHULUAN}

Sumatera Barat terus berupaya pengembangan ekonomi lokal melalui industri pariwisata. Salah satu daerah yang sedang melakukan pengembangan ekonomi berbasis pariwisata ini adalah Kabupaten Tanah Datar. Kabupaten Tanah Datar memiliki beraneka ragam Sumber Daya Alam dan Potensi wisata seperti danau, gunung, sungai dan lain sebagainya. Perkembangan Perekonomian di Kabupaten Tanah Datar belum terealisasi secara merata, ini terlihat masih kurangnya pembenahan dan pengembangan objek wisata yang berpotensi menjadi destinasi wisata di Kabupaten Tanah Datar. Pemerintah maupun swasta masih terfokus pada objek wisata yang sudah terkenal, sedangkan masih banyak objek wisata yang berpotensi menjadi destinasi wisata namun belum dikembangkan secara maksimal.

Salah satu objek wisata di Kabupaten Tanah Datar yang masih belum dikembangkan secara maksimal adalah Nagari Gunuang Rajo terletak di Kecamatan Batipuh. Secara geografis Nagari Guanuang Rajo terletak kaki Gunung Merapi yang membujur dari arah Timur ke Barat yang diapit oleh dua buah sungai yaitu Batang Lubuk Punago dan batang Gadih. Nagari Gunuang Rajo merupakan salah satu nagari dari delapan nagari yang berada di Kecamatan Batipuh dengan luas \pm 512 Ha terdiri dari 2 jorong dengan jumlah penduduk \pm 1.979 Jiwa.

Salah satu nagari yang berada di Kecamatan Batipuh kabupaten Tanah Datar Adalah Nagari Gunuang Rajo. Kenagarian ini memiliki banyak potensi yang bisa dikembangkan. Namun kesiapan masyarakat untuk mengembangkan Potensi Tersebut perlu diperhatikan. Walinagari Gunung Rajo melalui masyarakat Nagari Gunuang Rajo merupakan kelompok yang melakukan pengembangan yang salah satu dalam bidang organisasi ada bagian seksi pemberdayaan sumber daya manusia dan seksi pengembangan usaha. Bagian ini merupakan bagian yang nantinya memikirkan usaha yang bisa dikelola untuk penyediaan kenangan yang bisa dibawa pulang oleh wisatawan pulang. Namun bagian ini menemukan masalah-masalah dalam pengembangan usaha sebagai bentuk pemberdayaan masyarakat dalam peningkatan perekonomian seperti: belum adanya sentral oleh-oleh yang bisa menampung produk yang dihasilkan masyarakat dilingkungan Nagari Gunuang Rajo dan masyarakat belum mampu memasarkan produk yang dihasilkan.

Peningkatan adalah sebuah cara yang dilakukan untuk memperoleh kemampuan menjadi lebih baik. Perekonomian adalah upaya mengelola ekonomi pada suatu kelompok yang bertujuan untuk meningkatkan kesejahteraannya. Perekonomian sering dikaitkan dengan pendapatan masyarakat dalam bentuk upah, gaji, bunga, laba, dividen, dan pembayaran transfer (Femy, 2014). Tujuan dari peningkatan ekonomi adalah kesejahteraan, yang terlihat dari terbukanya lapangan usaha, reinvestasi, pemenuhan kebutuhan pokok, pengembangan sumber daya manusia, meningkatkan sektor pertanian, serta pembangunan desa (Rosyidi, 2006).

\section{METODE PELAKSANAAN}

Metode dalam penelitian ini adalah kualitatif dengan teknis analisis data deskriptif kualitatif. Metode kualitatif tepat digunakan dalam penelitian ini karena memberikan informasi yang lebih detail terkait dengan kondisi di lapangan. Hasil wawancara kepada informan kunci merupakan data primer yang digunakan sebagai acuan, kemudian didukung dengan data hasil observasi, serta data sekunder dari penelitian maupun laporan dari penelitian sebelumnya. Informan kunci dalam penelitian ini adalah wali nagari Gunung Rayo, jajaran Kerapatan Adat Nagari (KAN), serta masyarakat sebagai pelaku. Penelitian dilakukan selama 6 bulan, mulai dari bulan Juni hingga November 2019. 


\section{HASIL DAN PEMBAHASAN}

Kegiatan pengabdian dilakukan dengan tujuan meningkatkan perekonomian masyarakat di nagari Gunung Rajo. Bentuk kegiatan yang dilakukan adalah pelatihan masyarakat dalam mengelola potensi dan memasarkan produk yang dihasilkan sehingga bernilai jual lebih tinggi dibandingkan dengan potensi dasarnya. Usaha meningkatkan kualitas sumber daya masyarakat terus diupayakan, namun usaha tersebut masih belum memperoleh hasil yang memuaskan serta merata dan menyeluruh. Program-program yang menunjang pengetahuan dan keterampilan bidang pemasaran produk olahan berbasis pelatihan langsung bersama praktisi yang dilakukan secara berkelanjutan menjadi solusi untuk meningkatkan perekonomian masyarakat.

Pemberdayaan merupakan strategi yang tepat dalam meningkatkan ekonomi, sosial, dan transformasi budaya. Proses ini dapat menciptakan pembangunan yang menjangkau masyarakat dari berbagai latar belakang ekonomi untuk meningkatkan kesejahteraannya.

Potensi Gunung Rajo

Potensi lokal adalah kekayaan alam, budaya, dan Sumber daya Manusia pada suatu daerah (Paramitha, 2018). Potensi alam disuatu daerah bergantung pada kondisi geografis, iklim, dan bentang alam daerah tersebut. Kondisi alam yang berbeda tersebut menyebabkan perbedaan dan ciri khas potensi lokal setiap wilayah. Kekhasan bentang alam, perilaku dan budaya masyarakat setempat, dan kesejahteraan masyarakat membentuk segitiga interaksi yang saling berkaitan. Pembangunan dan pengembangan potensi lokal suatu daerah harus memperhatikan ketiga unsur tersebut.

Buah Durian Gunung Rajo memiliki rasa dan aroma yang khas, konon rasanya berbeda dengan Durian pada umumnya. Salah satu alasannya adalah kepercayaan masyarakat, bahwa buah durian di kebun mereka tidak boleh dipetik sebelum masanya. Buah durian yang dipetik ketika masih muda dipercaya akan menyebabkan gagal panen di Nagari tersebut. Buah durian yang tua (masak) memiliki rasa dan teksture yang lebih baik, dan menjadi lebih nikmat ketika disantap di sekitar tanaman tersebut berada. Hal ini menjadi potensi untuk mengembangkan pariwisata minat khusus, menanti durian jatuh dari pohon dan menikmatinya bersama-sama. Kegiatan ini tentu saja hanya dapat dilakukan dengan panduan dari masyarakat yang memiliki pengetahuan terkait dengan siklus tanaman durian.

Atraksi wisata minat khusus ini tentu saja membutuhkan waktu yang lebih panjang bagi wisatawan, dan tantangannya adalah ketersediaan durian yang siap hidang di sekitar Nagari Gunung Rajo. Agrowisata durian pada akhirnya tetap akan bertahan sebagai atraksi wisata minat khusus, dengan kata lain masyarakat harus menerima keuntungan yang terbatas dari usaha yang telah dikelolanya.

Usaha Pengelolaan Hasil

Hasil forum group disscusion antara tim pengabdi, masyarakat, dan jajaran nagari menunjukkan bahwa masalah utama yang dialami masyarakat adalah pengelolaan hasil panen durian. Selama ini, yang dilakukan masyarakat hanyalah menjual duriannya kepada pengepul, hampir $85 \%$ warga masyarakat melakukan kegiatan tersebut. Sisanya, $15 \%$ anggota masyarakat menjual sendiri hasil panennya di depan rumah maupun ke pasar. Masyarakat belum mampu mengolah hasil panen yang melimpah menjadi produk yang bernilai ekonomi lebih tinggi. Tim pengabdi Fakultas Pariwisata dan Perhotelan UNP membantu masyarakat melakukan pengelolaan produk durian, sehingga bernilai jual lebih tinggi dan mampu meningkatkan kesejahteraan masyarakatnya juga. 


\section{Suluah Bendang: Jurnal Ilmiah Pengabdian Kepada Masyarakat}

Vol.20, No.2, 2020

Kurnia Illahi Manvi 1, Lise Asnur 2, Arif Ardian 3, Retnaningtyas Susanti 4

Kemampuan masyarakat dalam mengolah produk durian didukung dengan bantuan dari tim pengabdi dalam bentuk peralatan, sehingga produk dapat lebih menarik pasar. Durian merupakan tanaman hutan yang pada perkembangannya berubah menjadi tanaman pekarangan dan bahkan menjadi perkebunan (Sobir dan Napitupulu, 2010). Durian terkenal memiliki prospek yang bagus seperti beberapa jenis buah lainnya, hal ini terlihat dari berbagai proses pengelolaannya menjadi bagian dari kegemaran masyarakat (Mukminati, 2012).

\section{Peningkatan Ekonomi}

Peningkatan ekonomi merupakan upaya mendasar yang harus dilakukan oleh pemampu kepentingan untuk membantu mencapai kesejahteraan masyarakatnya. Masyarakat Gunung Rajo, lebih dari 70\% lahannya digunakan untuk pertanian, dan lebih dari 80\% masyarakatnya berprofesi sebagai petani. Salah satu upaya peningkatan ekonomi yang dapat dilakukan adalah dengan memanfaatkan potensi pertanian tersebut. Program pendampingan yang telah dilakukan oleh tim pengabdi dari UNP telah berhasil meningkatkan ekonomi masyarakat. Setidaknya terdapat 20 orang ibu rumah tangga yang telah memiliki keahlian mengolah produk durian, melakukan pengelolaan keuangan, dan menghitung laba usaha.

Holtikultura atau pertanian merupakan sektor yang saat ini menjadi fokus perhatian pemerintah. Pengembangan terhadap pertanian mendukung tujuan swasembada pangan, meningkatkan pendapatan masyarakat dan memperbaiki keadaan gizi melalui penganekaragaman jenis bahan makanan (Kementerian Pertanian Ditjen Hortikultura, 2013). Salah satu yang menjadi perhatian dalam penelitian ini adalah produk durian yang jika dikelola dengan baik dapat membantu masyarakat meningkatkan pendapatannya secara berkelanjutan. Hal yang perlu diperhatikan dari pengembangan produk durian adalah memperoleh pendapatan berkelanjutan adalah ketersediaan produk. Masyarakat Nagari Gunung Rajo telah berusaha dengan mengembangkan produk olahan durian menjadi berbagai bentuk yang lebih menarik pembeli.

Pembelian produk olahan masyarakat Gunung Rajo secara langsung memerikan peningkatan ekonomi bagi masyarakat. Produk tidak dijual pada satu periode, seperti dengan menjual buah durian yang masih ada di batang secara keseluruhan, melainkan memanen sendiri hasilnya, kemudian menyimpannya sebagai bahan produk selanjutnya. Salah satu contoh dari peningkatan nilai durian terlihat dari harga. Pada masa durian berbuah lebat, satu tangkai durian kondisi bagus (besar dan tidak busuk) dapat dihargai 15.000-25.000. Satu tangkai durian tersebut ketika ditambah dengan bahan adonan menjadi dodol durian dapat bernilai 100.000-150.000 rupiah. Artinya terdapat peningkatan ekonomi yang siginifikan di masyarakat. Produk yang telah mengalami peningkatan harga membutuhkan sebuah tempat yang serupa workshop untuk menjajakan, sehingga konsumen lebih mudah mengakses. Tim pengabdi memberikan bantuan berupa peralatan untuk menjajakan produk tersebut berupa etalase, dan bangunan toko sebagai pusat penjualan produk. Masyarakat memperoleh peningkatan ekonomi dari kegiatan produksi dan sekaligus dari kegiatan penjualan produk tersebut.

\section{KESIMPULAN}

Peningkatan ekonomi masyarakat penghasil durian di Gunung Rajo telah menunjukkan hasil yang signifikan. Pelatihan dan pendampingan yang dilakukan oleh Tim UNP berhasil membantu masyarakat menemukan cara untuk menambah pendapatan dan kesejahteraannya dengan mengolah durian. Produk yang telah memiliki peningkatan nilai memberikan peningkatan ekonomi karena harganya yang semakin tinggi, dan yang terpenting adalah berkelanjutan. Buah durian yang sebelumnya memiliki jangka waktu penjualan rendah dapat menjadi lebih tinggi, sehingga keuntungan yang diperoleh dapat continue, tidak lagi 
dipengaruhi oleh musim. Pengabdian yang dilakukan oleh Tim UNP berhasil membantu masyarakat meningkatkan perekonomiannya, kegiatan ini perlu dilakukan secara berkelanjutan, sehingga menciptakan hasil yang menyeluruh, tidak terkotak-kotak oleh periode waktu.

\section{DAFTAR PUSTAKA}

Femy, M.G. (2014). Peningkatan pendapatan masyarakat melalui program pemberdayaan di desa Lolah III Kecamatan Tombariri, Kabupaten Minahasa. Jurnal LPPM Bida EkoSosBudKum, 1(1), 92-102.

Kementerian Pertanian, 2013. Petunjuk Teknis Pengembangan Buah. Jakarta: Direktorat Jenderal Hortikultura.

Mukminati, Sukma dan Harisudin, Mohd. (2012). Strategi Pemasaran Durian Sarangan di Kecamatan Matesih Kabupaten Karanganyar dengan Metode Competitive Profile Matrix (CPM). Jurnal Sosial Ekonomi Pertanian, 1 (1), 15-32.

Paramita, M., Muhlisin, S., \& Palawa, I. (2018). Peningkatan Ekonomi Masyarakat Melalui Pemanfaatan Sumber Daya Lokal. Qardhul Hasan: Media Pengabdian kepada Masyarakat4(1), 19-30.

Rosyidi, Suherman. (2006). Pengantar Teori Ekonomi: Pendekatan kepada Teori Ekonomi Mikro dan Makro. Jakarta: PT. Raja Grafindo Persada.

Sobir dan Napitupulu. (2010). Bertanam Durian Unggul. Penebar. Jakarta: Swadaya. 